\author{
Samad Mirza Suzani \\ Department of English, Marvdasht Branch, Islamic Azad \\ University, Marvdasht, Iran
}

\title{
THORNS AND FLOWERS OF TEACHING ENGLISH LITERARY CRITICISM TO THE SPEAKERS OF PERSIAN AS A GLOBALLY LESS WIDELY TAUGHT LANGUAGE: A CASE OF MA STUDENTS OF TRANSLATION STUDIES IN IRAN
}

\begin{abstract}
Summary. The main aim of this study is to probe into major impediments in teaching literary criticism to the Persian speaking Iranian students of translation studies and to argue in which ways teaching literary criticism may be a successful undertaking in the educational establishments in globally less widely taught and learnt languages like Persian. For this purpose, following a mandatory literary criticism course, 35 male and 65 female graduate students from Fars and Isfahan universities were selected through convenience sampling and encouraged to fill in "record-of-work" forms, including reflection on learning strategies as well as their personal experiences and impressions. Next, to triangulate the results, fifty participants were selected to partake in semistructured interviews, and findings were sorted and content analyzed based on Oxford's (1990) dimensions of Strategy Inventory for Language Learning (SILL) and the tenets of grounded theory. It was revealed that there exist major defects with the current sociopragmatic and pedagogical status of teaching literary criticism to the Iranian MA students and educational gaps are typically ascribed to the learners' cultural conditions in Iranian EFL context. Results can hopefully provide EFL teachers with ways to recover defects in teaching literary criticism in less widely taught and learnt languages and provide learners with immediate feedback to meet cultural requirements in doing literary criticism.
\end{abstract}

Keywords: EFL context; Iranian graduate programs; literary criticism; MA students; Persian; translation studies (TS).

\section{Introduction}

In the current system of Iranian graduate studies, the course of literary criticism constitutes an important component in the English MA program the aim of which is to introduce students to literary theories and approaches and train them to critically interpret and analyze various literary genres when translating from English to Persian and vice versa. However, it seems that the merits and objectives of this course have either been misunderstood or difficult to achieve. The thesis of this study is that literary criticism in translation class in Iranian universities, as it stands, can, for the most part, only have academic 
rather than professional goals. Besides, as a major compulsory course of MA in translation studies, literary criticism is one of the most challenging courses to teach at Iranian universities. This course has in fact been included in the curriculum to introduce to students a variety of critical approaches to literature. Considering that, faculty members who teach this course are required to cover a range of theories that often negate or dialectically complete each other. Each of these theories offers certain possibilities but also has some limitations in the critical reading of literary texts. Besides, even when introduced to an easily applicable approach in literary criticism, students typically do not display much enthusiasm for engaging in critical reading. Consequently, literary criticism classes are often conducted through the single voice of a professor who, in the literal sense of the word, "professes" to his audience the moral or social "message" of the text with very little participation in the discussion by his/her students.

With regard to the above considerations, one of the predominant concerns for most Iranian MA students of TS is to learn how to do literary criticism successfully, while EFL teachers' main concern is mostly to establish a common understanding of reflection-on-practice. Besides, as critical analysis is a special type of literary analysis that is required in literary criticism in TS and is more commonly known in graduate-level literature classes, and a capacity for critical thinking is central to learning, so involvement of students in reflection on their professional practice and academic development underpins program learning and teaching processes.

Another problem is that what most Iranian EFL university teachers in the literary criticism course observe is that a majority of the MA students of translation studies seek an approach which offers them a "complete" strategy for decoding every aspect of texts. As a result, literary criticism classes are often conducted through the single and authoritative voice of a professor with very little participation in the discussion by his/her students. Hence, if learners know how to perform literary criticism, they will work at the level of deep critical thinking, as do learners in advanced humanities classes.

Considering Persian as a less widely taught and learned language in the world, the main aim of this study is to probe into major impediments in teaching literary criticism to the Iranian students of translation studies and to argue in which ways teaching literary criticism may be a successful undertaking 
in the educational establishments. Accordingly, the following research questions are addressed:

1. What are major impediments of teaching literary criticism in Iranian educational settings?

2. In which ways can teaching a literary criticism course boost critical thinking among the Iranian MA students of Translation Studies?

\section{Literature review}

A number of empirical studies have investigated the evolution of critical thinking skills as students proceed through college level. Hanley (1995) maintained that critical thinking derives from cognitive and metacognitive processes; while the cognitive skills operate with information and data, which are isolated, then encoded, integrated, organized, transformed, stored and retrieved, metacognitive skills are used in monitoring and controlling mental processes and the various states of knowledge. Besides, King (1995) argued that metacognitive skills take as their object the cognitive skills, wherein they involve the conscious, planned, informed, deliberate control of (a) how to think and (b) what to think in order to maximize progress and minimize error (p. 16).

In a meta-analysis of eight studies, Gellin (2003) concluded that college students who engaged in interacting with faculty and peers and participating in college clubs increased their measured critical thinking skills by 0.14 standard deviations as compared to those who did not participate in such activities. Also, O'Hare and McGuinness (2009) found that the critical thinking scores of junior students in Ireland were significantly higher than the corresponding scores of freshmen and concluded that attending university exerts an independent effect on the development of critical thinking.

Kuhn (1999) postulated a developmental progression of critical thinking skills and synthesized a wealth of empirical research on cognitive development to construct such a progression. Her definition of critical thinking drew from the literature on metacognition, being viewed as related to critical thinking, which distinguished three forms of metacognition: metacognitive understanding, meta-strategic knowing, and epistemological understanding.

Halpern (1998) maintained that humans are programmed to look for patterns, particularly in the form of cause-and-effect relationships, and 
concluded that many adults fail to think critically in many situations. Likewise, Van Gelder (2005) concluded that many adults lack basic reasoning skills due to deficient educational experiences. Paul (1992) believed that typical school instruction does not encourage the development of higher-order thinking skills like critical thinking but lower-order learning, which is simply learning by rote or association, with the end result that students memorize material without understanding the logic of it.

Despite evidence suggesting that the average person struggles to think critically, many researchers are optimistic about the capacity of humans to become critical thinkers with appropriate instruction. Based on Kennedy et al. (1991), empirical research suggests that students of all intellectual ability levels can benefit from critical thinking instruction. Similarly, Lewis and Smith (1993) believe that critical thinking skills are for everyone, not just the gifted.

\section{Method}

In this qualitative study it was aimed to find an answer to "what" and "how" questions. Also, due to the dynamic and vibrant nature, it took advantage of the constructive qualities of grounded theory proposed by Glaser and Strauss (1967), Strauss and Corbin (1998).

\section{Participants}

The participants of this research were 35 male and 65 female Iranian MA students of Translation Studies from the universities of Fars and Isfahan, Iran. The participants were selected through convenience sampling and had passed the literary criticism as a compulsory course in the preceding term.

\section{Instruments}

An assessed out-of-class analysis project was directed, as part of which students were encouraged to fill in "record-of-work" forms to be submitted in a portfolio at the end of the project (Appendix 1). Also, semi-structured 
interviews were conducted to make up for the limitations of the portfolio's questionnaires (Appendix 2).

\section{Procedures}

By using "record-of-work" forms, which included a space for critical thinking on learning activities, the subjects were allowed to write their critical analyses to review previous works before making new ones. It also allowed the researcher to collect data in an easily accessible form at the end. The data collected were then put in a revised version of Oxford's (1990) dimensions of strategy classification for the Strategy Inventory for Language Learning (SILL) including metacognitive strategies, memory strategies, compensatory strategies, affective strategies, and social strategies. To gain more data that might be missing in the "record-of-work" forms, relevant semi-structured interviews were conducted with 50 participants on the pedagogical and socio-pragmatic status of literary criticism. Due to the limitations in time and space, the interviews were conducted with a half of the total population so that the participants could openly discuss different aspects of the issues in questions. The final data consisted of a combination of writing tasks from participants who did one or two more analytic writing(s) and wrote their comments on their own analyses, and a collection of participants' responses in the semi-structured interviews.

In analyzing the data, classification for the SILL by Oxford (1990) was considered for participants' critical strategies. Likewise, basic tenets of "grounded theory", initiated by Glaser and Strauss (1967) and extended by Strauss and Corbin (1998) were employed, which consist of a set of systematic, but flexible, guidelines for conducting inductive qualitative inquiry aimed toward theory construction. The focus of this theory is squarely on the analytic phases of research, and so both data collection and analysis inform and shape each other and are conducted in tandem.

Based on the features of the grounded theory, in this study it was primarily aimed to generate theory via the systematic review and classification of data collected, and then it was attempted to elaborate on data categorization via their relationships in the process of interpretation. Thus, the students' analyses were approached as direct evidence of the learners' ability to critically 
think upon their learning experiences which were triangulated with semistructured interviews to be categorized, sorted and then content analyzed.

\section{Results}

The data collected via students' end-of-project "record-of-work" forms revealed thought-provoking points. Drawing on Oxford's (1990) dimensions of strategy classification for the Strategy Inventory for Language Learning (SILL) some samples of learners' impressions are presented in Table 1:

Table 1.

Critical strategies along with samples of learners' impressions

\begin{tabular}{|l|l|}
\hline $\begin{array}{l}\text { Critical } \\
\text { Strategy }\end{array}$ & Learners' Impression/Experience \\
\hline Metacognitive & $\begin{array}{l}\text { "Writing in English literature in my education has been always } \\
\text { weird, time-consuming and laborious for me." } \\
\text { "We were not actually required to think and write much critically } \\
\text { beyond the writing exercises in our books at high school or pre- } \\
\text { university classrooms." } \\
\text { "Planning an argumentative essay takes me a lot of time and } \\
\text { energy thinking of different things. You know you need to think and } \\
\text { take sides." } \\
\text { "...it's more convenient for me to write about my experiences or } \\
\text { describe an event or my lifestyle or my culture. Then, I know more } \\
\text { words and can write more..." }\end{array}$ \\
\hline $\begin{array}{l}\text { "I come across many new words and structures every week. So I } \\
\text { almost always forget to use them while I do critical writing and thus } \\
\text { get frustrated at times. } \\
\text { "I sometimes write down new terms in literary writing but it is so } \\
\text { hard to use them all while doing a critical writing because of the } \\
\text { complexity." } \\
\text { "We really do not have enough time to review new words or } \\
\text { syntactic structures we come across, especially literary terms and } \\
\text { techniques as well as structures which are different from Persian } \\
\text { are kind of hard to remember and use while writing, so we just use } \\
\text { them infrequently." } \\
\text { "In attempting to do a reflective writing in literature, I almost give } \\
\text { up using some new syntactic structures in my critical essays since } \\
\text { they often turn out to be wrongly used. Actually, I try to avoid using } \\
\text { them or use them only when I'm absolutely certain about them." }\end{array}$ \\
\hline
\end{tabular}




\begin{tabular}{|c|c|}
\hline $\begin{array}{l}\text { Critical } \\
\text { Strategy }\end{array}$ & Learners' Impression/Experience \\
\hline Compensation & $\begin{array}{l}\text { Avoidance } \\
\text { "I use only the words I know...and mainly try to write the language } \\
\text { forms I've learned." } \\
\text { "I try to use a synonym or simpler writing style if I do not remember } \\
\text { a particular form, but most of the time I'm not so sure if they are } \\
\text { the right words." } \\
\text { "I feel at loss thinking and writing about literary things and topics. } \\
\text { I'm not interested in the topics abstract to me. Thus, I almost } \\
\text { always avoid writing about them." } \\
\text { Neat writing } \\
\text { "...My teacher and peers enjoy my neat writing, and tell me they } \\
\text { like that." } \\
\text { "I believe one of the good things which get me some extra marks } \\
\text { is my neat paragraph writing. Some of my friends think it is not } \\
\text { worth the trouble, but I don't think so." } \\
\text { Developing Outline/Plan in Persian/English } \\
\text { "Preparing the outline in Persian to write from helps to write with } \\
\text { less chaos." } \\
\text { "I write ideas in Persian on a piece of paper and try to include those } \\
\text { points as I write in English." } \\
\text { "I design a rough outline in English first and build up on that. This } \\
\text { is great especially while taking a writing exam that requires critical } \\
\text { thinking." } \\
\text { "Thinking in English helps me let my writing flow in English.also I } \\
\text { draw a quick English outline on top of my paper." }\end{array}$ \\
\hline Affective & $\begin{array}{l}\text { "I can gather up my energy really more strongly when I am writing } \\
\text { critically on literary genres at home in my study." } \\
\text { "Now I encourage myself to use more literary texts in English, and } \\
\text { this is fantastic. I like that." } \\
\text { "Before this, I really felt fear toward literature and writing critical } \\
\text { literary essays, even one sentence in English. Now I feel more at } \\
\text { ease with it." }\end{array}$ \\
\hline Social & $\begin{array}{l}\text { "Some of my friend's English literature and writing abilities is good, } \\
\text { so I ask them to correct my errors in critical literary writing." } \\
\text { "...the teacher just ticks off the end of my paper, or sometimes he } \\
\text { writes 'Good', or 'Excellent' at the bottom. I get pleased. But, to tell } \\
\text { the truth, I don't get much out of it... I myself know there are still } \\
\text { some wrong points there." } \\
\text { "The 'crosses' and the 'question' marks make me confused. I go to } \\
\text { great pains to understand what they mean all over my text." } \\
\text { "I think cultural understanding of a foreign language and culture } \\
\text { can help me think and write more native-like." }\end{array}$ \\
\hline
\end{tabular}


Considering the pedagogical and sociopragmatic aspects of literary criticism course, the results of the inquiry on 5-odd themes on different issues of literary criticism course are presented in Table 2.

Table 2.

Results of the inquiry on the pedagogical and socio-pragmatic status of literary criticism

\begin{tabular}{|c|c|c|c|c|c|c|}
\hline \multirow[t]{2}{*}{ No } & \multirow[t]{2}{*}{ Issue / theme no. } & 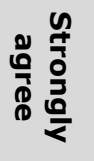 & 定 & $\begin{array}{l}z \\
0 \\
\overline{0} \\
\frac{0}{8}\end{array}$ & 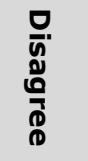 & 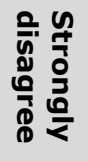 \\
\hline & & Freg. & Freg. & Freg. & Freg. & Freg. \\
\hline \multirow{2}{*}{1.} & \multirow{2}{*}{$\begin{array}{l}\text { Iranian EFL students' ignorance of } \\
\text { literary criticism (Theme 3) }\end{array}$} & N5 & 28 & 10 & 7 & 0 \\
\hline & & $10 \%$ & $56 \%$ & $20 \%$ & $14 \%$ & $0 \%$ \\
\hline \multirow{2}{*}{2.} & \multirow{2}{*}{$\begin{array}{l}\text { Inadequate inclusion of literary } \\
\text { criticism in language syllabi } \\
\text { (Theme 1) }\end{array}$} & 4 & 18 & 26 & 2 & 0 \\
\hline & & $8 \%$ & $36 \%$ & $52 \%$ & $4 \%$ & $0 \%$ \\
\hline \multirow{2}{*}{3.} & \multirow{2}{*}{$\begin{array}{l}\text { Criticality as a severe problem in } \\
\text { the course (Theme } 2 \text { ) }\end{array}$} & 9 & 30 & 8 & 3 & 0 \\
\hline & & $18 \%$ & $60 \%$ & $16 \%$ & $6 \%$ & $0 \%$ \\
\hline \multirow{2}{*}{4.} & \multirow{2}{*}{$\begin{array}{l}\text { Large extent of literary criticism's } \\
\text { semantic opaqueness (Theme } 3 \text { ) }\end{array}$} & 11 & 24 & 10 & 4 & 0 \\
\hline & & $22 \%$ & $48 \%$ & $20 \%$ & $8 \%$ & $0 \%$ \\
\hline \multirow{2}{*}{5.} & \multirow{2}{*}{$\begin{array}{l}\text { The reason behind literary } \\
\text { criticism's semantic opaqueness } \\
\text { (Theme 1) }\end{array}$} & 9 & 10 & 14 & 14 & 3 \\
\hline & & $18 \%$ & $20 \%$ & $28 \%$ & $28 \%$ & $6 \%$ \\
\hline \multirow{2}{*}{6.} & \multirow{2}{*}{$\begin{array}{l}\text { Learners' ability to surmise on why } \\
\text { literary criticism is used (Theme } 3 \text { ) }\end{array}$} & 4 & 28 & 8 & 9 & 1 \\
\hline & & $8 \%$ & $56 \%$ & $16 \%$ & $18 \%$ & $2 \%$ \\
\hline \multirow{2}{*}{7.} & \multirow{2}{*}{$\begin{array}{l}\text { No language fluency without } \\
\text { literary criticism course (Theme } 1 \text { ) }\end{array}$} & 11 & 25 & 10 & 3 & 1 \\
\hline & & $22 \%$ & $50 \%$ & $20 \%$ & $6 \%$ & $2 \%$ \\
\hline \multirow{2}{*}{8.} & \multirow{2}{*}{$\begin{array}{l}\text { Lack of notice to literary criticism, } \\
\text { creating 'academic lacuna' } \\
\text { (Theme } 1 \text { ) }\end{array}$} & 5 & 30 & 12 & 2 & 1 \\
\hline & & $10 \%$ & $60 \%$ & $24 \%$ & $4 \%$ & $2 \%$ \\
\hline \multirow{2}{*}{9.} & \multirow{2}{*}{$\begin{array}{l}\text { Literary criticism dearth in the } \\
\text { current English courses and text } \\
\text { books (Theme 1) }\end{array}$} & 7 & 30 & 7 & 6 & 0 \\
\hline & & $14 \%$ & $60 \%$ & $14 \%$ & $12 \%$ & $0 \%$ \\
\hline \multirow{2}{*}{10.} & \multirow{2}{*}{$\begin{array}{l}\text { The need to include aspects of } \\
\text { criticality to textbooks (Theme } 1 \text { ) }\end{array}$} & 19 & 15 & 6 & 8 & 2 \\
\hline & & $38 \%$ & $30 \%$ & $12 \%$ & $16 \%$ & $4 \%$ \\
\hline \multirow{2}{*}{11.} & \multirow{2}{*}{$\begin{array}{l}\text { Learners' ability to appreciate } \\
\text { texts, not knowing about literary } \\
\text { criticism (Theme 3) }\end{array}$} & 6 & 28 & 7 & 9 & 0 \\
\hline & & $12 \%$ & $56 \%$ & $14 \%$ & $18 \%$ & $0 \%$ \\
\hline \multirow{2}{*}{12.} & \multirow{2}{*}{$\begin{array}{l}\text { Literary criticism's exclusion as a } \\
\text { threat to the lofty pedagogical } \\
\text { standards (Theme 1) }\end{array}$} & 8 & 26 & 9 & 7 & 0 \\
\hline & & $16 \%$ & $52 \%$ & $18 \%$ & $14 \%$ & $0 \%$ \\
\hline
\end{tabular}




\begin{tabular}{|c|c|c|c|c|c|c|}
\hline \multirow[t]{2}{*}{ No } & \multirow{2}{*}{ Issue / theme no. } & 号 $\frac{n}{1}$ & 它 & 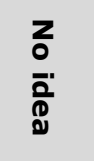 & 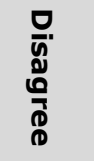 & 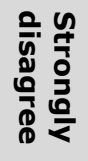 \\
\hline & & Freg. & Freg. & Freg. & Freg. & Freg. \\
\hline \multirow{2}{*}{13.} & \multirow{2}{*}{$\begin{array}{l}\text { Literary criticism as an inseparable } \\
\text { part of language teaching } \\
\text { (Theme 1) }\end{array}$} & 5 & 38 & 3 & 4 & 0 \\
\hline & & $10 \%$ & $76 \%$ & $6 \%$ & $8 \%$ & $0 \%$ \\
\hline \multirow{2}{*}{14.} & \multirow{2}{*}{$\begin{array}{l}\text { Learners need to learn and respect } \\
\text { literary criticism in their local } \\
\text { language (Theme } 4 \text { ) }\end{array}$} & 12 & 26 & 0 & 12 & 0 \\
\hline & & $24 \%$ & $52 \%$ & $0 \%$ & $24 \%$ & $0 \%$ \\
\hline \multirow{2}{*}{15.} & \multirow{2}{*}{$\begin{array}{l}\text { Literary criticism as one of the } \\
\text { necessities of a proficient } \\
\text { language learner (Theme } 4 \text { ) }\end{array}$} & 5 & 24 & 9 & 12 & 0 \\
\hline & & $10 \%$ & $48 \%$ & $18 \%$ & $24 \%$ & $0 \%$ \\
\hline \multirow{2}{*}{16.} & \multirow{2}{*}{$\begin{array}{l}\text { Literary criticism making language } \\
\text { learning process easier (Theme } 4 \text { ) }\end{array}$} & 5 & 28 & 10 & 7 & 0 \\
\hline & & $10 \%$ & $56 \%$ & $20 \%$ & $14 \%$ & $0 \%$ \\
\hline \multirow{2}{*}{17.} & \multirow{2}{*}{$\begin{array}{l}\text { The need to include more aspects } \\
\text { of literary criticism in language } \\
\text { courses (Theme } 4 \text { ) }\end{array}$} & 11 & 30 & 5 & 4 & 0 \\
\hline & & $22 \%$ & $60 \%$ & $10 \%$ & $8 \%$ & $0 \%$ \\
\hline \multirow{2}{*}{18.} & \multirow{2}{*}{$\begin{array}{l}\text { English literary criticism leading } \\
\text { learners to appreciate social and } \\
\text { pragmatic values (Theme 5) }\end{array}$} & 5 & 25 & 16 & 4 & 0 \\
\hline & & $10 \%$ & $50 \%$ & $32 \%$ & $8 \%$ & $0 \%$ \\
\hline \multirow[b]{2}{*}{19.} & \multirow{2}{*}{$\begin{array}{l}\text { Little knowledge of literary } \\
\text { criticism creating } \\
\text { misunderstandings in } \\
\text { communication (Theme } 5 \text { ) }\end{array}$} & 17 & 26 & 6 & 1 & 0 \\
\hline & & $34 \%$ & $52 \%$ & $12 \%$ & $2 \%$ & $0 \%$ \\
\hline \multirow[b]{2}{*}{20.} & \multirow{2}{*}{$\begin{array}{l}\text { EFL learners' need to be familiar } \\
\text { with the change(s) each } \\
\text { word/expression can bring about } \\
\text { (Theme } 3 \text { ) }\end{array}$} & 2 & 25 & 14 & 8 & 1 \\
\hline & & $4 \%$ & $50 \%$ & $28 \%$ & $16 \%$ & $2 \%$ \\
\hline \multirow[b]{2}{*}{21.} & \multirow{2}{*}{$\begin{array}{l}\text { Learners' familiarity with literary } \\
\text { criticism, making them conscious } \\
\text { of the linguistic, historical and } \\
\text { cultural overtones (Theme } 4 \text { ) }\end{array}$} & 2 & 14 & 11 & 22 & 1 \\
\hline & & $4 \%$ & $28 \%$ & $22 \%$ & $44 \%$ & $2 \%$ \\
\hline \multirow[b]{2}{*}{22.} & \multirow{2}{*}{$\begin{array}{l}\text { Learners' getting what's going on } \\
\text { in the language, language user's } \\
\text { minds, and culture by tracing } \\
\text { literary criticism (Theme } 4 \text { ) }\end{array}$} & 2 & 23 & 20 & 2 & 3 \\
\hline & & $4 \%$ & $46 \%$ & $40 \%$ & $4 \%$ & $6 \%$ \\
\hline \multirow{2}{*}{23.} & \multirow{2}{*}{$\begin{array}{l}\text { English literary criticism promoting } \\
\text { socio-pragmatic behavior of } \\
\text { learners (Theme 5) }\end{array}$} & 5 & 19 & 17 & 8 & 1 \\
\hline & & $10 \%$ & $38 \%$ & $34 \%$ & $16 \%$ & $2 \%$ \\
\hline \multirow[b]{2}{*}{24.} & \multirow{2}{*}{$\begin{array}{l}\text { Students need to a critical look at } \\
\text { literary criticism besides being } \\
\text { exposed to more of them in } \\
\text { language courses (Theme } 2 \text { ) }\end{array}$} & 7 & 24 & 14 & 5 & 0 \\
\hline & & $14 \%$ & $48 \%$ & $28 \%$ & $10 \%$ & $0 \%$ \\
\hline \multirow{2}{*}{25.} & \multirow{2}{*}{$\begin{array}{l}\text { Learners' positions towards } \\
\text { including literary criticism course } \\
\text { in the syllabus (Theme } 1 \text { ) }\end{array}$} & 4 & 28 & 10 & 3 & 5 \\
\hline & & $8 \%$ & $56 \%$ & $20 \%$ & $6 \%$ & $10 \%$ \\
\hline
\end{tabular}




\begin{tabular}{|c|c|c|c|c|c|c|}
\hline \multirow[t]{2}{*}{ No } & \multirow[t]{2}{*}{ Issue / theme no. } & 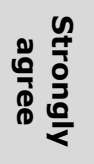 & 定 & $\begin{array}{l}z \\
0 \\
\overline{0} \\
0\end{array}$ & 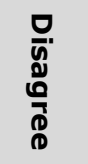 & 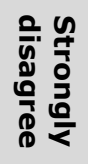 \\
\hline & & Freg. & Freg. & Freg. & Freg. & Freg. \\
\hline \multirow{2}{*}{26.} & \multirow{2}{*}{$\begin{array}{l}\text { Effectiveness of literary criticism } \\
\text { course in the syllabus (Theme } 1 \text { ) }\end{array}$} & 1 & 29 & 14 & 6 & 0 \\
\hline & & $2 \%$ & $58 \%$ & $8 \%$ & $12 \%$ & $0 \%$ \\
\hline \multirow{2}{*}{27.} & \multirow{2}{*}{$\begin{array}{l}\text { EFL students being unenlightened } \\
\text { about objectives of literary } \\
\text { criticism (Theme } 1 \text { ) }\end{array}$} & 5 & 32 & 8 & 5 & 0 \\
\hline & & $10 \%$ & $64 \%$ & $16 \%$ & $10 \%$ & $0 \%$ \\
\hline \multirow[b]{2}{*}{28.} & \multirow{2}{*}{$\begin{array}{l}\text { Literary criticism being appealing } \\
\text { in encircling a range of emotions, } \\
\text { reactions, attitudes and opinions } \\
\text { (Theme 3) }\end{array}$} & 1 & 40 & 6 & 3 & 0 \\
\hline & & $2 \%$ & $80 \%$ & $12 \%$ & $6 \%$ & $0 \%$ \\
\hline \multirow[b]{2}{*}{29.} & \multirow{2}{*}{$\begin{array}{l}\text { The need to critical thinking for } \\
\text { learners to reflect on both local } \\
\text { and English literary criticism } \\
\text { (Theme 2) }\end{array}$} & 1 & 20 & 16 & 12 & 1 \\
\hline & & $2 \%$ & $40 \%$ & $32 \%$ & $24 \%$ & $2 \%$ \\
\hline \multirow{2}{*}{30.} & \multirow{2}{*}{$\begin{array}{l}\text { Literary criticism's helping learners } \\
\text { to be better world citizens } \\
\text { (Theme 5) }\end{array}$} & 7 & 31 & 9 & 2 & 1 \\
\hline & & $14 \%$ & $62 \%$ & $18 \%$ & $4 \%$ & $2 \%$ \\
\hline
\end{tabular}

As revealed in Table 2, some evocative issues including inadequate inclusion or too little attention to literary genres in the syllabus, semantic opaqueness of literary terminology, absence of literary criticism course from curriculum and lack of notice to literary criticism course are visibly itemized by many participants. On the other hand, there are positive reactions to the postulation that literary criticism is considered as one of the necessities of a proficient language learner, as there appears to be a remarkable consensus among interviewees that no language fluency is imaginable without a logical degree of doing literary criticism; likewise, having no knowledge of literary criticism, the learners will be unable to appreciate texts and excluding it from language classroom will be a threat to the lofty pedagogical standards.

\section{Discussion}

Proportionate to the individuals' varying literary critical abilities and their responses in interviews several debatable points were noted. 


\section{End-of-project "record-of-work" portfolios}

With regard to Table 1 , as for metacognitive strategies, students maintained that they had conducted little writing on literary criticism in their education before, and that they had problems writing in particular literary genres. An interesting point was that they found writing narratives or descriptions most often less demanding than writing argumentative texts. They also referred to many factors including lack of time, difficulty, basic incompetency and traditional course requirements as main reasons.

Data concerning memory strategies showed that few Iranian TS graduates are familiar with mnemonic devices to improve their knowledge of language skills including critical writing skills. Moreover, they do not revise and contextualize novel vocabulary items or structures in their writing, which was corroborated through their portfolios.

As compensation strategies are revealing especially with respect to coining and avoidance strategies, findings show that only a limited number of students were inclined towards coining new phrases or expressions in cases when they did not remember the intended literary forms. This was in contrast with the behavior of the majority of the participants, who did not risk coining or rephrasing their intended meaning when their linguistic knowledge fell short. Instead, they mostly resorted to copying the original form of the words or expressions. Besides, most of the TS learners follow avoidance strategy. Writing on unfamiliar topics, especially literary topics, seems to hinder the developmental writing performance of them. Their writing performance also suffers as a result of the unfamiliar critical tasks, which reduces the learners' confidence and raises their anxiety, thus lowering their performance. As Horwitz (2000) found, highly anxious students make fewer attempts to convey difficult messages in the $\mathrm{TL}$, and it raises their anxiety, reduces their confidence, and eventually lowers their performance.

Another compensatory strategy pointed out by the participants was neat writing, as participants mentioned neat writing as one of the most important qualities in their critical writing. Also, differences were found between learners in some cognitive strategies related to sporadic translation and outlining. Less experienced learners tended to use more translation, especially when planning or outlining before writing, while some other learners 
preferred to produce an outline or plan in English and to develop their ideas from that outline rather than starting from Persian as their mother tongue. This group typically included more advanced students. The use of these strategies support the point maintained by Cohen and Brooks-Carson, (2001) that both planning and translation using the learner's first language may be helpful writing strategies related to individual and academic experience.

As for affective strategies, findings showed that after a few weeks from the beginning of the project most learners preferred a stronger tendency for enhancing their critical abilities in writing. Their confidence in language skills and their interest in writing critical tasks increased. They also believed that written communication could be more conducive to a better performance, and declared they enjoyed written literary texts more than they did at the beginning of the course.

As for social strategies, a point raised about the teacher's feedback, especially at the beginning of their literature classrooms, was that they had a hard time to figure out the teacher's intended written feedback given in the form of ticks, marks, crosses, etc. Furthermore, it was almost ever emphasized that the feedback participants got from their teachers and peers through the project was the most valuable to them which is line with Williams and Burden (1997) belief that the teacher's written feedback needs to be informational rather than simple and potentially confusing marks. That is, it should increase students' motivation towards certain aspects of the writing task and help them perform subsequent tasks with greater independence, criticality and confidence. The reason is that it has a mediatory function and will be considered helpful by the learner only when it generates a feeling of competence, confidence, individuality, and control. Also, the feedback should identify which aspects of their reflective writing are acceptable and capable of improvement, and thus help learners develop towards the acceptable level of writing development. In addition, the role of cultural understanding as an instrumental tool for critical writing development was emphasized. 


\section{Inquiry on the pedagogical and socio-pragmatic aspects of literary criticism}

Considering findings on different issues of literary criticism course represented in Table 2, the following 5-odd themes are discussed in details:

Theme 1: Raison d'etre, objectives and effectiveness in syllabus. With reference to the raison d'etre and effectiveness of English literary criticism in the syllabus, a number of responses seemed to be more logical, tenable, and relevant, which could show participants' relative degrees of awareness to literature and literary criticism. For instance, a participant maintained "Because doing textual analysis in literary criticism is most often along with different degrees of ambiguity, it fails to be appealing for many learners, especially the novice ones. Hence, in a broad sense we may say that this course can also be regarded as special case that asks for special attention on behalf of both teachers and learners." Another participant maintained "If the course could be offered with scheduled clarification and relevancy it can help to better understanding of criticism objectives." Still, another one asserted "Because English literary criticism is an inseparable part of English literature, so by ignoring it we cannot be faithful to learning critically and comprehensively, and also we don't pay attention to other linguistic nuances." In contrast, some interviewees seemed to be too conservative, conformist, and middle-of-the-road, taking no sides in their responses: "I think it depends on the audience, and their knowledge of understanding the literary criticism." Then again, some responses appeared to be too general, hazy, or even shallow wherein the participants could not present a plain piece of their mind. A participant said "Learners can use literary criticism to achieve the excellence in language learning. It may improve their critical skills and abilities." And another asserted, "I think the way of presenting the course is subordinate to literary criticism, as literary criticism is a refined, exulted form of language, and doing analysis is an integral part of it. Knowing a brief history of literature, literary approaches and literary elements is subsidiary for literary criticism."

Considering the objectives, a good number of respondents asserted that most EFL students are unenlightened about the objectives of literary criticism, as a student thought "I think that most of EFL students are unaware about the objectives of literary criticism while they are producing discourse or 
when they are exposed to it, e.g., some learners may do literary criticism in their classrooms, but most of them often wonder what a good criticism is." Another interviewee believed that "Without familiarity with literary criticism or just knowing little about it, learners cannot use or understand literature and hence they will be confused. But if they learn critically, they have no problem with it." On the contrary, there were some comments a bit different from the above viewpoints:

"I think it depends on each individual. Maybe there are some students who are not familiar with literary criticism course and its objectives in mother language and foreign language."

"Knowing about aspects of literary criticism is really hard. Students should know about their culture to understand the objectives of it, and so the ways they should use it need a lot of time."

Regarding the effectiveness of literary criticism course in the syllabus, some responses seemed to be more pertinent, reasonable, and defensible, which indicated the interviewees' perceptiveness of the literature and literary criticism course:

\begin{abstract}
"It is better to use further literary courses such as literary criticism in the syllabus, because it may lead to increased awareness in learners and make them better analytic thinkers." "In my opinion, a main objective of literature is to make a good and idealistic society. So the learners should stop keeping away from literary courses such as literary criticism."

"I think in some cases we should enhance use of English literary criticism in order to observe the main objectives defined in the curriculum. Also, despite complexities, it might be in line with many EFL learners' interests, wants, and needs. And because of the reasons mentioned, we should use literary criticism as an effective course in the curriculum."
\end{abstract}

However, some interviewees appeared to be too conservative and run of the mill in their remarks. For instance, one claimed "Although it can be claimed that we can use and understand language without applying literary criticism, it can help us to be more refined and well-educated in speech and behavior." Another argued, "Since some phrases or expressions in literary language may have different meanings and may show special connotations, it is better to enhance our critical abilities through literary criticism effectively." On the other 
hand, a number of responses seemed too general, indistinct, and obscure in which the participants did not provide a lucid idea or credible reason as to whether the use of literary criticism: "In the everyday language communication, the effects of literary criticism may be observed rarely directly. In fact, learners should use literary criticism expressions in a higher order hierarchy of language learning, and therefore, they shouldn't ignore it in the curriculum whatsoever."

Theme 2: Critical thinking. With reference to the critical thinking for EFL learners to reflect on both local and English literary criticism, a respondent maintained "I think language learner should have critical thinking about doing literary criticism in order to recognize the degree of criticality in the text and they should use different degrees of literary criticism according to the setting, person or text." And another said "By critical thinking skills learners learn how to do literary criticism deeply and do not memorize them superficially. Also, they learn to know the use of literary techniques and devices in the texts more professionally."

Theme 3: Learners' abilities, attitudes and emotions. A large number of stirring comments were offered concerning literary criticism being alluring in a range of emotions, reactions, and attitudes, and also as an aid to learners' becoming better world citizens. In this regard, a participant believed that "literary language, as in literary criticism can carry lots of emotions, reactions, attitudes and opinions within them, so that using it makes us more familiar with exact feelings of the speaker." Likewise, another student maintained "As real emotions, reactions, and attitudes are conveyed, the receivers get the same effect as producers, and they use outcomes of literary criticism in their actual language use." By the same token, with reference to literary criticism as a help to learners' becoming better world citizens, it was asserted "By knowing about it, learners can use the appropriate style in each status of social class. Then they can be better citizens in this regard." And another one claimed "Knowing about English literary criticism helps learners in society, because literary criticism is a neat and refined form of language that can be effectively used in communication."

Theme 4: Language and culture. Participants often asserted that by tracing literary criticism learners could get what's going on in the language, language user's minds, and culture: "Because cultures have something in 
common, learners can become aware of similarities by extending their knowledge about source and target cultures." Another respondent argued "As issues in literary criticism inspire from cultures, religions, values, and aesthetic features of a society, by knowing it learners can feel writer's aims more tangible." Nevertheless, there were some opposing comments to the above assumptions, as an interviewee objected "Literary criticism may not consider all aspects of language, and also the users of one language may have different cultures."

Theme 5: Communicative and social pragmatic values. Regarding little knowledge of literary criticism creating misunderstandings in communication, participants mostly maintained a confirmatory attitude. For instance, it was claimed that "If there is not enough knowledge about literary criticism, it may cause problems to perceive and convey some messages correctly." Also, it was confirmed by another comment: "Surely knowing little about literary criticism, not only creates various misunderstanding in communication, but it can be threatening and sometimes makes problem in communication."

Participants strongly held the idea that literary criticism often leads learners to appreciate social and pragmatic values; also, learners need to become familiar with the change(s) literary terms can bring about; in addition, their familiarity with literary criticism course could make them conscious of the historical and cultural overtones. Considering social and pragmatic values, it was maintained that "The way people communicate is part of their social behavior", and that "Knowing about English literary criticism in language courses causes some motivation in learning about social or pragmatic values." Regarding EFL learners' familiarity with the effects and outcomes of literary criticism it was asserted that "If we want to learn and understand a language perfectly, we should know what happens in it and be familiarized with all changes and know them." Likewise, concerning learners' consciousness of the linguistic, historical and cultural overtones, it was held that "By knowing how to do literary criticism, English learners can be familiar with different aspects of the linguistic background and cultural overtones." 


\section{Conclusion}

By qualitative and descriptive data in this study, it was indicated that it would be of interest and value to research into literary criticism from pedagogical and socio-pragmatic perspectives.

Concerning the first research question, the results revealed that the course has not been paid due attention as it deserves. Despite the momentous prominence of literary criticism, very slight attention has been paid to it at different college levels; and at present literary criticism suffers from sort of dearth and meagerness in the current English courses and textbooks. It was also indicated that few studies have been conducted on teaching literary criticism in the Iranian educational establishments, as the core of this course is to try to appreciate and explain what is not explicitly stated in the text, with a firm belief in the fact that the implied meaning of a text could be explored and examined from other perspectives too. Thus, it seems that lack of notice to the core of literary criticism, has created an 'academic lacuna' and hence it is needed to include aspects of criticality to textbooks so that students take a critical look at literary criticism besides being exposed to it in their language courses.

With reference to the socio-pragmatic facet of literary criticism, it was maintained that a potential threat to the Iranian EFL learners can be their being unenlightened about the cores and objectives of literary criticism when they are exposed to it, or when they are recognizing or producing literary discourses. A culture to which pluralism is alien also fosters students who constantly seek the "ultimate" in literary studies and so cannot make sense of divergent critical approaches. The very fact that normally very few faculty members volunteer to teach literary criticism and amongst students it has gained notoriety as a very "demanding" course is indicative of some of these difficulties. It may be argued that the problems teachers encounter in teaching this course stem from the dominant undemocratic attitudes which are incompatible with the nature of literary criticism. Also, due to the interdependence of culture and personal behavior, critical theory and practice cannot be possibly taught unless the teachers as well as their students believe in pluralism and the co-existence of opposing voices in real life and in interpersonal interactions. 
Despite literary criticism skill being assumed as one of the necessities of proficient language learners, EFL students were most often unenlightened about main objectives and mechanism of doing literary criticism, and sometimes they attributed it to the inadequate inclusion of literary criticism in their language courses. In this vein, literary criticism exclusion from the syllabus could be a threat to the lofty pedagogical standards. Thus, more aspects of literary criticism should be included in the syllabus, and learners need to figure out the rationale behind doing criticism and to respect it in the foreign and local cultures.

Another significant problem was concerned with learners' insufficiently appreciating literary texts, knowing little about literary criticism as well as semantic opaqueness. Due to the fuzziness in semantic sense, to many EFL learners, employing literary criticism could be tactfully or deliberately illusory. Because doing textual analysis in literary criticism is most often along with different degrees of ambiguity, it fails to be appealing for many learners. In addition, in the everyday language communication, the effects of literary criticism may be observed rarely directly. Thus, learners should be informed about the reason(s) for doing literary criticism to be able to use it in a higher order hierarchy of language learning, and not to ignore it in the curriculum whatsoever. On the other hand, teaching literary criticism seems a hard and often hopeless task because our audiences have not yet reached a high level of cultural and political self-consciousness so as to make democracy a structural element of their thinking. It seems self-evident that not all students are consistent in their approach to literature learning and criticism, and there are a range of factors such as maturity, previous learning experiences, academic qualifications, workplace experience and commitment which may influence learners' engagement. Domineering and submissive mindsets are equally unable to grasp or tolerate the pluralistic nature of literary theories. Literary criticism requires that we believe in democracy and that different and contradictory discourses could be involved in the critical reading of a text. Success in teaching literary criticism is inextricably bound up with cultural and political pluralism. This tendency explains why in literary criticism classes, despite teachers' repeated pleadings and despite rewarding students with bonus marks for participation in class discussions, the majority of our audience show no interest in making comments and tend to remain silent. This 
situation also clarifies why students usually prefer their teachers to make an interpretation of the text under consideration and thus make the job easy for all of them.

Regarding the second research question, it was found that though chiefly ignored up to the recent periods, literary criticism is gradually arousing EFL learners' interest, so that exciting and promising progress could gradually be made in their critical studies from various points of view.

Another notable point is the significant goal of literary criticism in communication, as it helps learners to get what's going on in the language, language user's minds, and culture by tracing details in literary criticism. Learners' familiarity with this course could also make them conscious of the linguistic, historical and cultural overtones. In this vein, offering literary criticism is a help to learners to be better world citizens, as it requires learners to do critical thinking on both local and universal aspects.

It was also found that literary criticism could promote socio-pragmatic behavior of learners as it is appealing in encircling a range of emotions, reactions, attitudes and opinions and it can lead learners to appreciate social and pragmatic values. Moreover, literary criticism can make language learning process easier. For this reason, having little knowledge of literary criticism can create misunderstandings in communication and language fluency without a sufficient command of literary criticism is almost impossible. Furthermore, through critical thinking activities within the program, it was aimed to enhance the quality of learning and teaching for students via increased levels of peer and tutor support and providing varied contexts for learning.

Theoretically speaking, studies of this kind can shed some more light on the current literature on pedagogy, by illuminating the characteristics of language which have been ignored in the previous studies. Furthermore, the issues provided could provide the readers with the ability to enhance effectiveness and comprehensiveness in detecting potential inculcations beyond idiomatic power of literary language.

There are a number of different factors, including rhetoric, stylistic and contextual ones that affect the pragmatic inference and appreciation of literary criticism and ultimately the expressive effect of it. Thus, it is advisable to attach great importance to these factors while paying constant attention to crosscultural differences in doing literary criticism. 
In general, language teachers, material developers, translators, and learners can benefit from the present study. Also, based upon the above discussion, the following pedagogical statements can be made:

1. The Iranian EFL teachers should make the learners aware of the cultural differences so that when they are reading English texts, they don't become surprised about the use of literary terms and expressions in that language. Also, they are advised to learn the contrast between literary and ordinary language, as this ability can give rise to booming literary criticism in language.

2. The students should be encouraged to enhance their ability in doing literary criticism in authentic texts, as it makes them better learners to use language more fruitfully; also, they ought to identify different genres in English literary criticism based on the scope of source, scope of sense, and sphere of application.

3. Learners should be able to recognize and appreciate aspects of literary criticism chief properties including history, approaches and elements; in the same vein, they should surmise, to a reasonable degree, why literary criticism is included in the syllabus.

4. The field of translation would also benefit from translators' awareness of English literary criticism and the differences in SL and TL cultures.

5. It is suggested that EFL learners, by probing into literary criticism, develop the essential power for critical thinking, fostering thoughtfulness, and perceptiveness via integrating stages of educational levels into a pattern for critical thinking and self-assessment.

The present study can be considered as a starting point for conducting more comprehensive research on the linguistic, pedagogical, and sociopragmatic aspects of literary criticism course and its relation with learners' critical thinking in Iran. It is, as well, hoped to open educators and scholars' perspectives to focus their attention further on this area of study in other EFL contexts whose language is not globally widely used. Also, more detailed endeavors are expected to be done on the analogous or related issues such as replicating the study by employing other literary courses, investigating the impact of literary genres/skills on language critical abilities, language awareness and language interpretation, and adopting strategies for doing 
literary criticism in particular genres. The study could raise some more challenging questions for the continued research such as the following:

1. How does an awareness of literary language and expressions affect students' language proficiencies and applied linguistic studies?

2. How could pedagogical programming be affected by an awareness of literary language and expressions in applied linguistic studies?

3. How could an awareness of literature be reflected in ordinary or everyday language?

In the same vein, as for the researchers interested in continuation of the current study, the following topics and issues are proposed as further suggestions:

1. Performing a comparative study can reveal many similar and/or different aspects of English and non-English literary criticism in use, means of formation, and communicative functions.

2. By conducting a comparative study the cultural similarities and/or differences reflected by literary criticism in English and non-English context could be disclosed.

3. A comparative study may also reveal the effect of literary criticism on the EFL learners' awareness of and using the English language skillfully in cross-cultural communication.

It should be pointed out that the research made in this study is undoubtedly open to further debate and argumentation, and so there could still be a variety of relative problems to be solved out of the researcher's restricted knowledge and materials. Therefore, this study can be considered as a starting point for further research on this area of study. In this vein, the author sincerely hopes this humble research will evoke more attention on the current situation of literary criticism course as well as other heated analogous or related issues on English literature.

\section{References}

Cohen, A. D., \& Brooks-Carson, A. (2001). Research on direct versus translated writing: Students' strategies and their results. The Modern Language Journal, 85, 169-188. 
Gellin, A. (2003). The effect of undergraduate student involvement on critical thinking: A meta-analysis of the literature 1991-2000. Journal of College Student Development, 44(6), 746-762.

Glaser, B.G. and Strauss, A.M. (1967). The Discovery of General Theory: Strategies for Qualitative Research. New York: Aldine.

Halpern, D. F. (1998). Teaching critical thinking for transfer across domains: Dispositions, skills, structure training, and metacognitive monitoring. American Psychologist, 53(4), 449-455.

Hanley, G. L. (1995). Teaching critical thinking: Focusing on metacognitive skills and problem solving. Teaching of Psychology, 22(1), 68-71.

Horwitz, E. K. (2000) It ain't over til it's over: On the foreign language anxiety, first language deficits, and the confounding of variables. The Modern Language Journal, 84, 256-259.

Kennedy, M., Fisher, M. B., \& Ennis, R. H. (1991). Critical thinking: Literature review and needed research. In L. Idol \& B.F. Jones (Eds.), Educational values and cognitive instruction: Implications for reform (pp. 11-40). Hillsdale, New Jersey: Lawrence Erlbaum \& Associates.

King, A. (1995). Designing the instructional process to enhance critical thinking across the curriculum. Teaching of Psychology, 22 (1), 13-16.

Kuhn, D. (1999). A developmental model of critical thinking. Educational Researcher, 28(2), 16-26.

Lewis, A., \& Smith, D. (1993). Defining higher order thinking. Theory into Practice, 32(3), 131-137.

O'Hare, L. O., \& McGuinness, C. (2009). Measuring critical thinking, intelligence, and academic performance in psychology undergraduates. The Irish Journal of Psychology, 30(3-4), 123-131.

Oxford, R. L. (1990). Language learning strategies: What every teacher should know. New York: Newbury House Publishers.

Paul, R. W. (1992). Critical thinking: What, why, and how? New Directions for Community Colleges, 1992(77), 3-24.

Strauss, A. L. \& Corbin, J. M. (1998). Techniques and Procedures for developing Grounded theory. London: Sage Publications.

Van Gelder, T. (2005). Teaching critical thinking: Some lessons from cognitive science. College Teaching, 53(1), 41-48. 
Williams, M. and Burden, L. R. (1997). Psychology for Language Teachers. Cambridge: Cambridge University Press.

\section{Samad Mirza Suzani}

Anglu kalbos katedra, Marvdasto filialas, Islamiškasis Azado universitetas, Iranas; smirzasuzani@yahoo.com

\section{ANGLU LITERATŪROS KRITIKOS MOKYMO KALBANTIEMS GLOBALIAI MAŽIAU PAPLITUSIA PERSU KALBA „SPYGLIAI IR GÉLĖS": MAGISTRANTŪROS VERTIMO STUDIJU STUDENTU IRANE TYRIMAS}

Santrauka. Pagrindinis šio tyrimo tikslas yra ištirti svarbiausias literatūros kritikos mokymo persiškai kalbantiems iraniečiams, studijuojantiems vertimo studiju programoje, kliūtis ir nustatyti, kokiais būdais literatūros kritikos mokymas gali tapti naudinga veikla globaliai mažiau paplitusiu kalbu, tokiu kaip persu, ugdymo istaigose. Šiam tikslui igyvendinti buvo atrinkti 35 vyriškos lyties ir 65 moteriškos lyties studentai iš Farso ir Isfahano universitetu, užbaigę privalomaji literatūros kritikos kursą. Tam buvo naudojamas patogumo atrankos metodas, pildomos darbo ataskaitos formos, taip pat apmastymai apie mokymosi strategijas ir individualia patirti bei ispūdžius. Be to, norint trianguliuoti rezultatus, 50 dalyviu atrinkti pokalbiui, kurio metu buvo naudojamas pusiau struktūrizuotuose interviu, o rezultatai klasifikuojami ir analizuojami naudojant turinio analizę, remiantis Oxford (1990) kalbos mokymosi strategiju tyrimo inventoriaus (SILL) aspektais ir grindžiamosios teorijos principais. Buvo nustatyti reikšmingi trūkumai, susiję su socialiniu, pragmatiniu ir pedagoginiu literatūros kritikos mokymo magistrantūros studentams Irane statusu, bei atskleista, jog ugdymo spragos dažniausiai priskiriamos besimokančiuju kultūrinèms salygoms anglu, kaip užsienio kalbos mokymo (EFL), kontekste Irane. Tikètina, kad rezultatai padès suprasti būdus, kaip anglu kalbos mokytojams panaikinti literatūros kritikos mokymo trūkumus mažiau paplitusiomis kalbomis, ir padès suteikti besimokantiesiems tiesiogini grižtamaji ryši, siekiant ivykdyti kultūrinius reikalavimus literatūros kritikoje.

Pagrindinès sąvokos: anglu kaip užsienio kalbos mokymo (EFL) kontekstas; absolventu programos Irane; literatūros kritika; magistrantūros studentai; persu kalba; vertimo studijos (TS). 